\title{
High-Density Poplar SRC Accumulates More Soil Organic Carbon Than Very-High-Density SRC
}

\author{
Chiara Ferré *, Gaia Mascetti and Roberto Comolli (D) \\ Department of Earth and Environmental Sciences, Milan Bicocca University, 20126 Milan, Italy; \\ gaia.mascetti@unimib.it (G.M.); roberto.comolli@unimib.it (R.C.) \\ * Correspondence: chiara.ferre@unimib.it
}

Citation: Ferré, C.; Mascetti, G.; Comolli, R. High-Density Poplar SRC Accumulates More Soil Organic Carbon Than Very-High-Density SRC Agronomy 2021, 11, 584. https:// doi.org/10.3390/agronomy11030584

Academic Editor: Emanuele Lugato

Received: 19 February 2021

Accepted: 17 March 2021

Published: 19 March 2021

Publisher's Note: MDPI stays neutral with regard to jurisdictional claims in published maps and institutional affiliations.

Copyright: (c) 2021 by the authors. Licensee MDPI, Basel, Switzerland. This article is an open access article distributed under the terms and conditions of the Creative Commons Attribution (CC BY) license (https:// creativecommons.org/licenses/by/ $4.0 /)$.
Abstract: Short rotation coppice (SRC) systems play an important role in producing renewable energy and contributing to soil organic carbon storage while providing potential mitigation for climate change. Our chronosequence study assessed the influence of 6 years of high-density $(\mathrm{H})$ and veryhigh-density (VH) SRCs on soil organic carbon (SOC) accumulation in an alluvial area of Piedmont (Italy) by investigating the effects of agronomic management (fertilization, irrigation, fertilization and irrigation, no treatment) using a spatial survey approach. A first sampling was performed at 40 points to characterize the variability of the initial SOC and other soil properties; 6 years after, a total of 80 samplings were carried out to verify changes in SOC. A mixed effect model procedure was used to evaluate the impact of 6 years of SRC and agronomic management on SOC, testing for autocorrelation among the model residuals. The results showed: (i) a higher accumulation potential of H-SRC (0.076 kg m $\mathrm{kg}^{-2}$ year $\left.{ }^{-1}\right)$ compared to VH-SRC (0.037 $\mathrm{kg} \mathrm{m}^{-2}$ year $\left.{ }^{-1}\right)$; (ii) a significant positive influence of the initial SOC value and of fertilization associated with irrigation on the SOC sequestration; (iii) the importance of considering spatial variability at sites with high particle-size diversity in evaluating the SOC changes.

Keywords: poplar; soil organic carbon stock; soil variability; chronosequence; bioenergy; agronomic treatments

\section{Introduction}

Climate change mitigation is one of the biggest challenges of our time and renewable energy sources play a fundamental role in reducing $\mathrm{CO}_{2}$ emission. The exploitation of biomass as an energy source has several advantages [1-3] and energy crops can also contribute to the $\mathrm{CO}_{2}$ emission offset through the maintaining or sequestering carbon in soil $[3,4]$.

Energy crop production systems may differ in term of species (herbaceous and woody) and management (density plantations, irrigation, fertilization, pest control, harvest frequency). Among woody crops, short rotation coppice (SRC) systems are defined as high-density plantations of fast-growing trees, characterized by short coppicing intervals (2-8 years) [5] and low requirement of technical inputs for fertilization, pest management, and tillage [6-8].

The most significant species cultivated in SRC systems are willow (Salix spp.) and poplar (Populus spp.), due to their fast growth rates, short breeding cycle, high yields production, broad genetic variability (which allows adaptation to different soil and climate conditions), and ability to be propagated vegetatively [9-11]. Other important species are red alder (Alnus rubra Bong), black locust (Robinia pseudoacacia L.), and Eucalyptus spp. [12].

To date, the growing importance of SRC has increased the area covered with these crops in many European countries and makes it necessary to evaluate their environmental sustainability, impacts on soil, and carbon sink potential $[8,13]$. Most studies have so far been conducted in temperate areas of Central and Northern Europe and Northern Italy [3-5,8,13-18]. A smaller number of studies have affected oceanic climate areas (UK 
and northwest France [19-22]) and Mediterranean climate areas (southeast Spain and Italy $[4,23,24])$.

The carbon balance of SRC depends on several factors, as cultivated species, climate, soil conditions, plantations management, and previous land-use; changes in soil carbon stock after plantation establishment occur until a new equilibrium is achieved.

Several studies shown an increase of soil organic carbon (SOC) after conversion from croplands to SRC [12], due to the high inputs of organic carbon from leaf and root litter and the minimal soil disturbance. However, losses in SOC stock were observed after conversion to SRC of native vegetation or perennial grasslands. This apparent contradiction is immediately explained: SOC accumulation rate is negatively correlated to the initial organic carbon stock in soil [13], which in turn depends on previous land-use. That is, soils with lower organic carbon content (such as intensively cultivated agricultural land) have a larger potential as organic carbon sink compared to other land.

As mentioned, SRC does not require high management efforts. Chemical and mechanical weed control is necessary only during the establishment period and after each harvest. Water consumption is site-specific and weather dependent, as well as the need of an irrigation system. In the Po valley and central Italy, water availability is one of the main factors influencing SRCs, so irrigation must always be taken into account to prevent yield losses during the dry years [14]. The need for fertilization depends on site and soil conditions. N-fertilizer demand is generally quite low, due to effective $\mathrm{N}$ recycling, although willow seems to require more nitrogen than poplar [14]. To date, the effects of fertilization on carbon accumulation in SRC soils are still uncertain. Indeed, the few authors $[13,15]$ who have studied the correlation between fertilization and SOC have obtained contradictory results.

SRC plantations also significantly affect the vertical distribution of carbon in soil profile [8], creating a carbon concentration gradient with soil depth.

Some studies have shown a decrease in SOC during the first year after the conversion to SRC $[11,17,25]$, presumably due to tillage of the ploughed layer, followed by an increase $[13,25,26]$. Other studies found an increase from the early years $[13,23]$, while one otherobserved no significant variation [11].

Few authors have studied medium-term variations in SOC stock, reporting an initial decrease of SOC stock followed by an increase reaching the pre-plantation level within 7 years [15,25]. Ceotto and Candilo (2011) [16] observed a consistent increase already in the first 7 years.

Most long-term studies found an increase in SOC stock over time after conversion to SRC as consequence of the higher inputs from litters compared to the losses due to decomposition [8].

This variability confirms that carbon sequestration is influenced by various environmental and management factors [13]. Moreover, it reflects the uncertainty due to a series of simplifying assumptions (linearity, steady state) and to datasets often based on comparison of plantations at different age, while detailed chronosequences are the exception [11].

In all the mentioned studies, SOC results were obtained from the average of individual sampling points without considering soil spatial variability.

We present here the results of a chronosequence study, part of the SUSCACE project (http:/ / www.gruppo-panacea.it/biomasse / progetti/suscace; accessed on 18 March 2021), which aims to investigate the conversion of agricultural lands from food production to SRC poplar plantations for bioenergy. In particular, the objectives of our study were to: (i) assess the influence of 6 years of high-density and very-high-density SRCs on SOC using a spatial survey approach, (ii) evaluating the effects of the agronomic management (fertilization, irrigation, fertilization and irrigation) on SOC changes in each investigated SRC type. 


\section{Materials and Methods}

\subsection{Study Site}

The experimental site is located near the Po river at Casale Monferrato (Piedmont, Italy; $45^{\circ} 08^{\prime} 07.77^{\prime \prime} \mathrm{N} ; 08^{\circ} 30^{\prime} 42.16^{\prime \prime} \mathrm{E}$ ), in a CREA (Italian Council for Agricultural Research and Economics) experimental farm.

The climate is temperate continental (average rainfall $715 \mathrm{~mm}_{\text {year }}{ }^{-1}$ and average temperature $12.5^{\circ} \mathrm{C}$ ). Since the parent material consists of recent alluvial deposits, soils are poorly developed: according to World Reference Base (WRB) classification [27] they are Calcaric Regosols (Epiloamic, Endoarenic, sometimes Endoskeletic) [18]. The soils are mostly sandy loam on the surface and loamy sand at depth, sometimes with a significant amount of rock fragments; they have moderate limestone content and are slightly alkaline.

The study area ( $1 \mathrm{ha}$ ) has been uniformly managed as arable land or poplar plantation for several decades; in 2006 it was cultivated with alfalfa and in 2009 it was divided into two fields for an experimental SRC study, in order to verify the performance of the Imola poplar clone (Populus $x$ canadensis Mönch).

Two models were tested:

- High-density-H-SRC: 1111 trees/ha, with $3 \times 3 \mathrm{~m}$ spacing and harvesting every 5 years;

- $\quad$ very-high-density-VH-SRC: 8333 trees/ha, with $3 \times 0.4 \mathrm{~m}$ spacing, with first harvest at the end of the first year and every two years thereafter.

For both the models, 4 types of agronomic management were tested using a split-plot experimental scheme with three randomized blocks [28]. Each block was split in half, and irrigation was allocated at random to one half of the block. Each irrigation plot was split into two subplots, and fertilization was allocated at random to one of the subplots. As a result, two treatments were applied (irrigation and fertilization) with two levels each: 'no' and 'yes'; the investigated types of agronomic management were:

- $\quad$ no treatment (CTR);

- $\quad$ irrigation (I): calibrated according to the potential evapotranspiration rate and distributed during the summer, when required, with a drip system;

- fertilization (F): $60 \mathrm{~kg} \mathrm{ha}^{-1}$ year $^{-1}$ of slow-release nitrogen, applied in early spring;

- fertilization and irrigation (FI).

Plots were ploughed to a depth of $35 \mathrm{~cm}$ and then harrowed. Unrooted 1-year old poles, planted at $70 \mathrm{~cm}$ depth, were used to establish H-SRC; unrooted cuttings, $20 \mathrm{~cm}$ long, were employed for VH-SRC.

Harrowing and insecticide treatments were carried out to eliminate weeds and combat poplar pests, respectively. During the planting year and the first SRC year, disc harrowing was carried out in the lanes (approx. $15 \mathrm{~cm}$ depth) twice in the VH-SRC and only once in the H-SRC. During the cultivation period, the harrowing was carried out once per year for both the stands.

\subsection{Soil Sampling and Analysis}

A soil survey was carried out in spring 2010 to characterize the variability of soil properties with the aim of identifying the most suitable locations for the monitoring of soil greenhouse gas emissions [18]. This first soil sampling has been considered here as the initial condition (starting point) against which to assess changes in SOC stock as a consequence of SRC.

The soil was sampled by layers, the thickness of which was decided on the basis of the average limits of the genetic horizons, as described in the soil profiles [18]: 0-15 cm (Ap1 horizon, corresponding to the thickness of harrowing); $15-35 \mathrm{~cm}$ (Ap2 horizon, up to the depth reached by the initial ploughing); 35-60 cm (AC horizon, up to the depth reached in the past in the deep ploughing that was used to establish poplar plantations). A total of 40 points (20 in H-SRC, 20 in VH-SRC) randomly chosen were sampled using a steel 
cylindrical volumetric sampler (5.4 cm diameter) for the first two layers and a gouge auger (30 mm diameter-Eijkelkamp, Giesbeek, The Netherlands) for the third one.

Soil samples were air dried, sieved ( $2 \mathrm{~mm}$ mesh), and analyzed to determine the SOC and total nitrogen (Ntot) content (Flash EA 1112 NCSoil, Thermo Fisher Scientific elemental analyzer, Pittsburgh, PA, USA), after carbonate removal by $\mathrm{HCl}$ [29], $\mathrm{pH}$ in $\mathrm{KCl}$ $(1 \mathrm{M})$ and $\mathrm{pH}$ in water (soil to $\mathrm{KCl}$ solution/water ratio of 1:2.5), particle-size distribution by sieving and sedimentation [30] (sand, $0.05-2 \mathrm{~mm}$; silt, 0.002-0.05; clay, $<0.002 \mathrm{~mm}$ ), and total carbonates (Dietrich-Frühling calcimeter, in the $0-15 \mathrm{~cm}$ layer only). The bulk density of the fine earth (BD) was calculated from the sampler volume and corrected for the rock fragments volume.

A second spatial survey, performed with the same methods and criteria, took place 6 years later in summer 2016 at 80 total points (40 in H-SRC and 40 in VH-SRC; Figure 1). In the second sampling, only organic carbon was measured, to verify changes from the previous one.
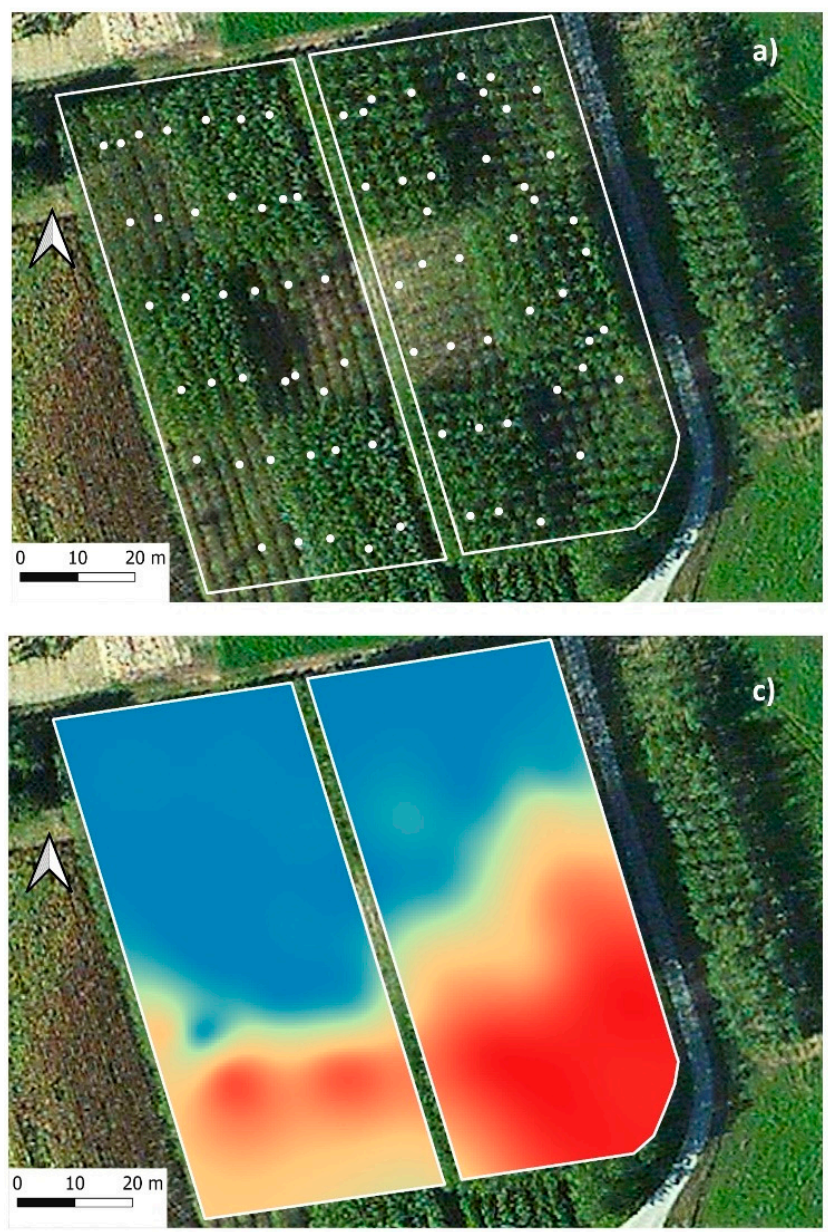
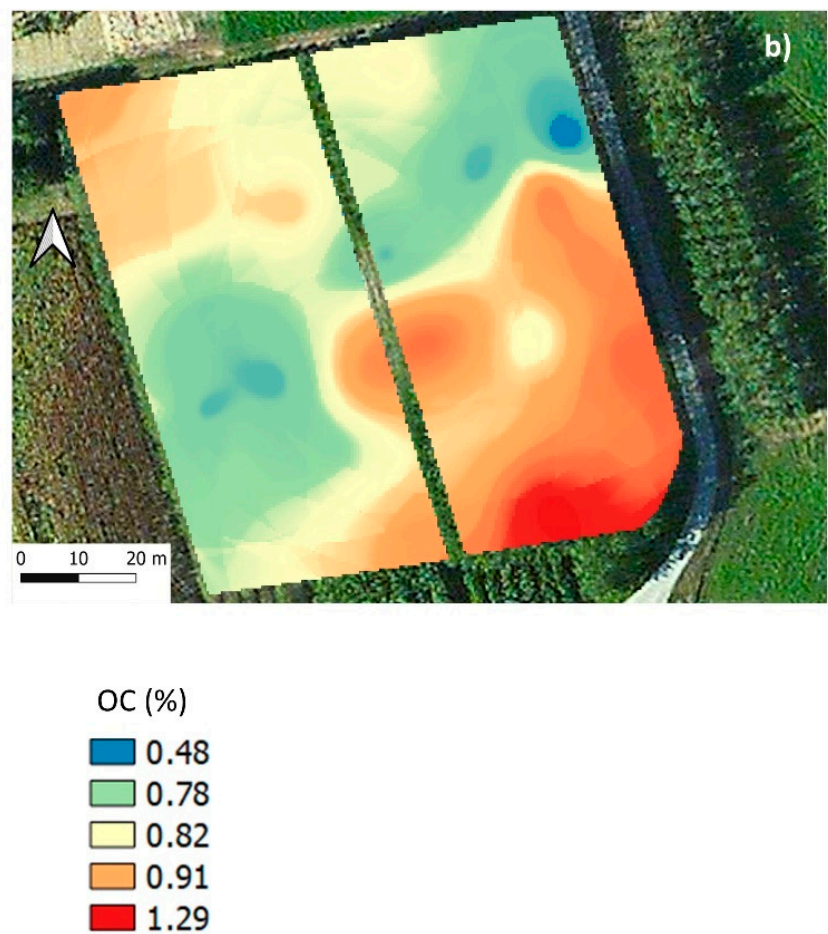

RF (\%)

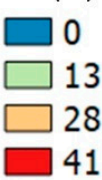

Figure 1. (a) Study site and sampling points; (b) map of initial soil organic carbon content (OC); (c) map of rock fragment (RF) content.

The SOC stock (expressed in $\mathrm{kg} \mathrm{m}^{-2}$ ) was calculated for each layer from the SOC content (\% by weight), taking into account fine earth BD and rock fragments volume (RF).

\subsection{Statistical and Geostatistical Analyses}

For each SRC type, data analyses were performed in different steps: (1) investigation of the effect of 6 years of SRC on SOC stock; (2) geostatistical analyses of SOC content, $\mathrm{RF}$, and BD to obtain spatial estimates of the starting SOC content and stock and thus (3) perform the subsequent regression models to assess agronomic management influence 
on SOC changes by taking into account the initial SOC (starting point); (4) application of the models to estimate spatial distribution of SOC stock after 6 years of SRC for the entire study area and consequently obtain map of SOC increments.

\subsubsection{Univariate and Multivariate Geostatistical Analyses}

Multivariate geostatistical (cokriging) procedure [31] was applied to the SOC content obtained from the first 2010 sampling) and sand content in order to disclose the spatial relationships among the variables and obtain the SOC content estimates at the nodes of a $0.5 \times 0.5 \mathrm{~m}$ cell grid. Univariate geostatistical technique was used to estimate BD and RF content and thereby calculate the initial SOC stock both at the nodes of the same grid and at the point locations sampled to characterize the SOC stock after 6 years of SRC (2016 data).

A prior Gaussian transformation of the raw variables was carried out through Gaussian anamorphosis, which uses an expansion of Hermite polynomials [32,33]. The goodness of fit was evaluated with cross-validation by calculating: (1) mean error, and (2) root mean square standardized error by (co)kriging variance.

All geostatistical analyses were performed using ISATIS-neo release 10.1 software package [34].

\subsubsection{Evaluation of Effects on SOC}

To evaluate the effects of 6 years of SRC cultivation and agronomic management on SOC, a mixed effect model procedure was performed testing for autocorrelation among the model residuals [35].

SOC stock changes after 6 years were evaluated considering the duration of SRC permanence (starting point and 6 years of SRC) as a fixed effect in the model. For the third layer only, we made the comparison in terms of content and not stock due to the difficulty of measuring the RF volume.

Agronomic management effect on SOC after 6 years of SRC was investigated considering as fixed effect the treatment (F, I, FI, and CTR) and including in the model the previously estimated initial SOC value; the differences between the mean values were obtained through contrast analysis.

Statistical analyses were performed with PROC MIXED of SAS software package (release 9.4; SAS Institute, Cary, NC, USA) [36]. The simultaneous estimates of covariance parameter and fixed effect coefficients were obtained by restricted maximum likelihood (REML) estimation [36]. A general absence of autocorrelations among model residuals was observed.

The models were applied to the maps of initial SOC, with the aim of obtaining the distribution map and the average value of SOC stock after 6 years of SRC and consequently the maps of its increments for each plantation type.

\section{Results}

The starting SOC content by weight, measured in the first sampling, ranged between 0.48 and $1.29 \%$ in the $0-15 \mathrm{~cm}$ layer (Table 1 and Figure 1 ) with an average value \pm standard deviation of $0.91 \pm 0.23 \%$ in H-SRC and $0.82 \pm 0.12 \%$ in VH-SRC. Below the depth of the harrowing, the SOC content was $0.78 \pm 0.19 \%$ in the second investigated layer, decreasing to $0.69 \pm 0.17 \%$ in the third. The C:N ratio of SOM was around 10 at the surface, slightly lower at depth.

The soil texture (USDA class) of the topsoil was mainly sandy loam, the soil reaction was subalcaline, with average values of $7.7,7.9$, and 8.2 in the $0-15 \mathrm{~cm}, 15-35 \mathrm{~cm}$, and $35-60 \mathrm{~cm}$ layers, respectively, and the total carbonates were in limited quantities $\left(58 \pm 8 \mathrm{~g} \mathrm{~kg}^{-1}\right)$.

The study area was characterized for almost half by the presence of RF till a maximum of $40 \%$ by volume, mainly distributed in the southeast part of H-SRC. The variability of soil particle size greatly affected the spatial distribution of SOC stock which in the first layer averaged to $1.52 \pm 0.22 \mathrm{~kg} \mathrm{~m}^{-2}$, ranging between 1.09 and $2.07 \mathrm{~kg} \mathrm{~m}^{-2}$. 
Table 1. Main statistics of initial soil properties of the investigated layers (I: 0-15 cm; II: $15-35 \mathrm{~cm}$; and III: $35-60 \mathrm{~cm}$ ).

\begin{tabular}{|c|c|c|c|c|c|c|c|c|c|c|c|c|}
\hline & \multicolumn{3}{|c|}{ Mean } & \multicolumn{3}{|c|}{ St.dev } & \multicolumn{3}{|c|}{ Min } & \multicolumn{3}{|c|}{ Max } \\
\hline & $\mathbf{I}$ & II & III & $\mathbf{I}$ & II & III & I & II & III & I & II & III \\
\hline $\mathrm{pH}$ & 7.7 & 7.9 & 8.2 & 0.1 & 0.1 & 0.1 & 7.6 & 7.8 & 8.1 & 7.8 & 8.0 & 8.5 \\
\hline SOC (\%) & 0.86 & 0.78 & 0.69 & 0.19 & 0.17 & 0.13 & 0.49 & 0.57 & 0.49 & 1.29 & 1.36 & 0.89 \\
\hline $\mathrm{CN}$ & 10.2 & 9.7 & 9.4 & 0.94 & 0.72 & 0.65 & 8.3 & 7.2 & 7.8 & 11.6 & 11.8 & 11.4 \\
\hline Sand $\left(\mathrm{g} \mathrm{kg}^{-1}\right)$ & 592 & 582 & - & 47 & 78 & - & 490 & 437 & - & 668 & 785 & - \\
\hline Silt $\left(\mathrm{g} \mathrm{kg}^{-1}\right)$ & 356 & 364 & - & 43 & 74 & - & 280 & 174 & - & 450 & 501 & - \\
\hline Clay $\left(\mathrm{g} \mathrm{kg}^{-1}\right)$ & 52 & 54 & - & 6 & 9 & - & 39 & 38 & - & 66 & 71 & - \\
\hline $\mathrm{TC}\left(\mathrm{g} \mathrm{kg}^{-1}\right)$ & 58 & - & - & 8 & - & - & 36 & - & - & 74 & - & - \\
\hline $\mathrm{BD}\left(\mathrm{g} \mathrm{cm}^{-3}\right)$ & 1.41 & 1.43 & 1.30 & 0.07 & 0.10 & 0.11 & 1.26 & 1.08 & 1.05 & 1.55 & 1.55 & 1.47 \\
\hline $\mathrm{RF}(\%)$ & 15 & 18 & - & 15 & 17 & - & 0 & - & - & 40 & 45 & - \\
\hline SOCstock $\left(\mathrm{kg} \mathrm{m}^{-2}\right)$ & 1.52 & 1.85 & - & 0.22 & 0.29 & - & 1.09 & 1.42 & - & 2.06 & 2.49 & - \\
\hline
\end{tabular}

pH: pH in water; SOC: organic carbon content; $\mathrm{CN}$ : C:N ratio; sand; silt; clay; TC: total carbonates; BD: bulk density; RF: rock fragments; SOCstock: organic carbon stock.

After 6 years of SRC, the SOC stock of the $0-15 \mathrm{~cm}$ layer significantly ( $p$-value $<0.05$ ) increased both in H-SRC and VH-SRC (Table 2), while no significant differences in SOC were found for the second and the third investigated layers.

Table 2. Effect of 6 years of (a) high-density (H)-short rotation coppice (SRC) and (b) very-highdensity (VH)-SRC on SOC: coefficient estimates and their standard error of the fixed effect (duration of SRC permanence: starting point and 6 years of SRC). The response variable is SOC stock $\left(\mathrm{kg} \mathrm{m}^{-2}\right)$ for the first two layers $(0-15 \mathrm{~cm}$ and $15-35 \mathrm{~cm})$ and SOC content $(\%)$ for the third one. Significant differences $(p<0.05)$ are in bold.

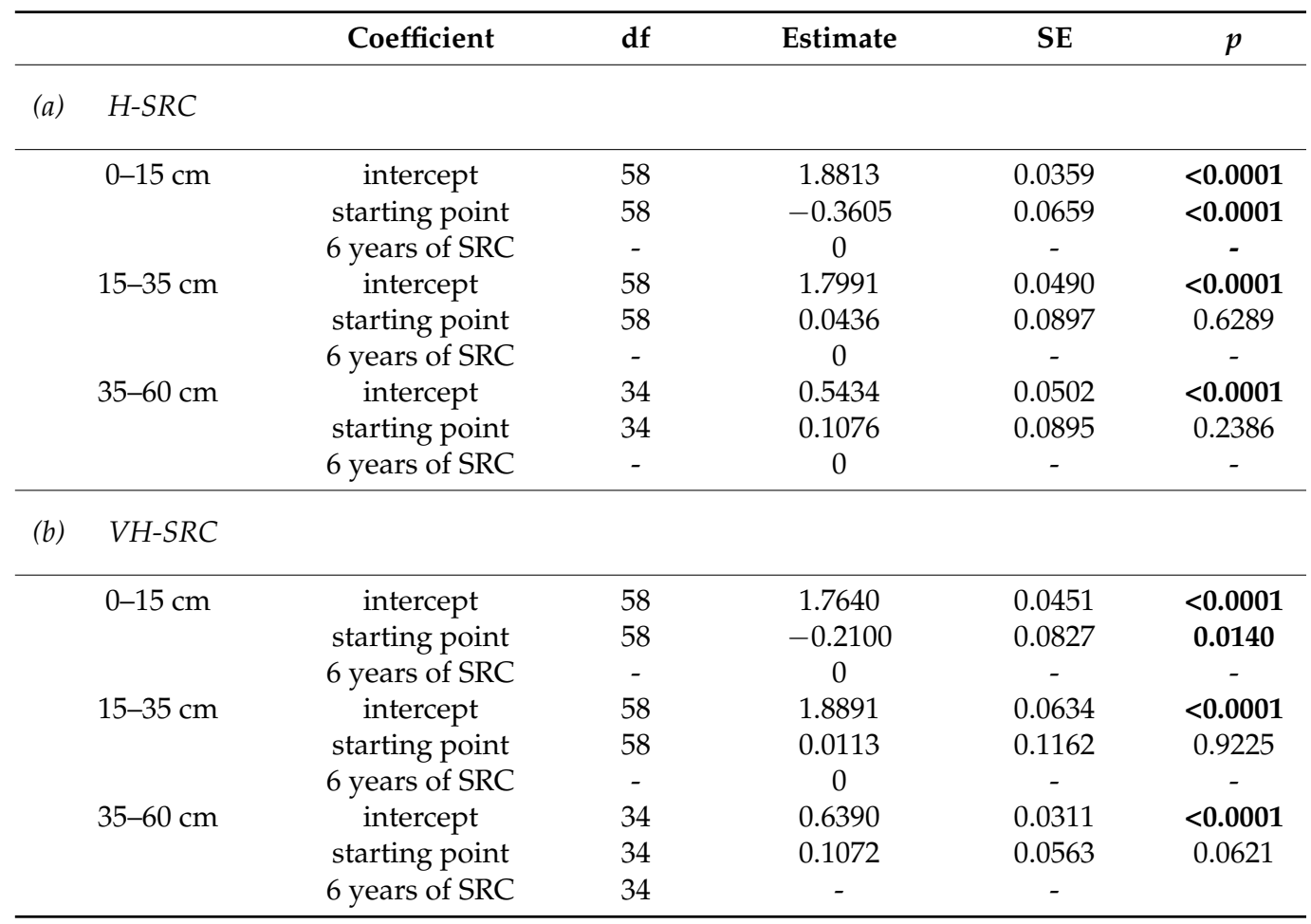

As consequence of the non-involvement of deeper soil layers in the 6 years of SRC, the investigation effect of the agronomic management was performed for the first layer only, showing a significant positive influence of the FI treatment on the accumulation of SOC; this increase significantly depends on the initial SOC value (Table 3). In general, in the study area, the SOC stock increment, defined as the difference between the SOC stock measured after the 6 years of SRC and that at the starting point at the same locations, was significantly negative related to the initial SOC stock (Figure 2). 
Table 3. Effects of 6 years of agronomic treatments on SOC and differences between the mean values (contrast analysis): coefficient estimates and their standard error of the models for topsoil SOC as a function of initial SOC and treatments (I: irrigation; F: fertilization; FI: fertilization and irrigation; CTR: control) for (a) H-SRC and (b) VH-SRC. Significant differences $(p<0.05)$ are in bold.

\begin{tabular}{|c|c|c|c|c|c|}
\hline$H-S R C$ & Coefficient & df & Estimate & SE & $p$ \\
\hline \multirow[t]{6}{*}{$\mathrm{SOC}(\%)$} & intercept & 35 & -1.2774 & 0.4016 & 0.0031 \\
\hline & initial OC (\%) & 35 & 2.7017 & 0.4123 & $<0.0001$ \\
\hline & $\mathrm{F}$ & 35 & 0.2360 & 0.1353 & 0.0897 \\
\hline & FI & 35 & 0.4345 & 0.1363 & 0.0030 \\
\hline & CTR & 35 & 0.2799 & 0.1569 & 0.0832 \\
\hline & I & - & 0 & - & - \\
\hline \multirow[t]{7}{*}{ contrast analysis } & treatment & treatment & estimate & SE & $p$ \\
\hline & $\mathrm{F}$ & FI & -0.1985 & 0.1320 & 0.1415 \\
\hline & $\mathrm{F}$ & CTR & -0.0438 & 0.1506 & 0.7727 \\
\hline & $\mathrm{F}$ & I & 0.2360 & 0.1353 & 0.0897 \\
\hline & $\mathrm{FI}$ & CTR & 0.1547 & 0.1501 & 0.3100 \\
\hline & FI & I & 0.4345 & 0.1363 & 0.0030 \\
\hline & CTR & $\mathrm{I}$ & 0.2799 & 0.1569 & 0.0832 \\
\hline VH-SRC & Coefficient & df & Estimate & SE & $p$ \\
\hline \multirow[t]{6}{*}{$\operatorname{SOC}\left(\mathrm{kg} \mathrm{m}^{-2}\right)$} & intercept & 35 & 0.8145 & 0.1977 & 0.0002 \\
\hline & initial OC $\left(\mathrm{kg} \mathrm{m}^{-2}\right)$ & 35 & 0.5347 & 0.1250 & 0.0002 \\
\hline & $\mathrm{F}$ & 35 & 0.1786 & 0.0930 & 0.0635 \\
\hline & FI & 35 & 0.3136 & 0.0925 & 0.0018 \\
\hline & CTR & 35 & 0.07145 & 0.0897 & 0.4318 \\
\hline & I & - & 0 & - & - \\
\hline \multirow[t]{7}{*}{ contrast analysis } & treatment & treatment & estimate & SE & $p$ \\
\hline & $\mathrm{F}$ & FI & -0.1349 & 0.0941 & 0.1611 \\
\hline & $\mathrm{F}$ & CTR & 0.1072 & 0.0918 & 0.2516 \\
\hline & $\mathrm{F}$ & I & 0.1786 & 0.0930 & 0.0635 \\
\hline & FI & CTR & 0.2421 & 0.0917 & 0.0126 \\
\hline & FI & I & 0.3136 & 0.0925 & 0.0018 \\
\hline & CTR & I & 0.0714 & 0.0897 & 0.4318 \\
\hline
\end{tabular}

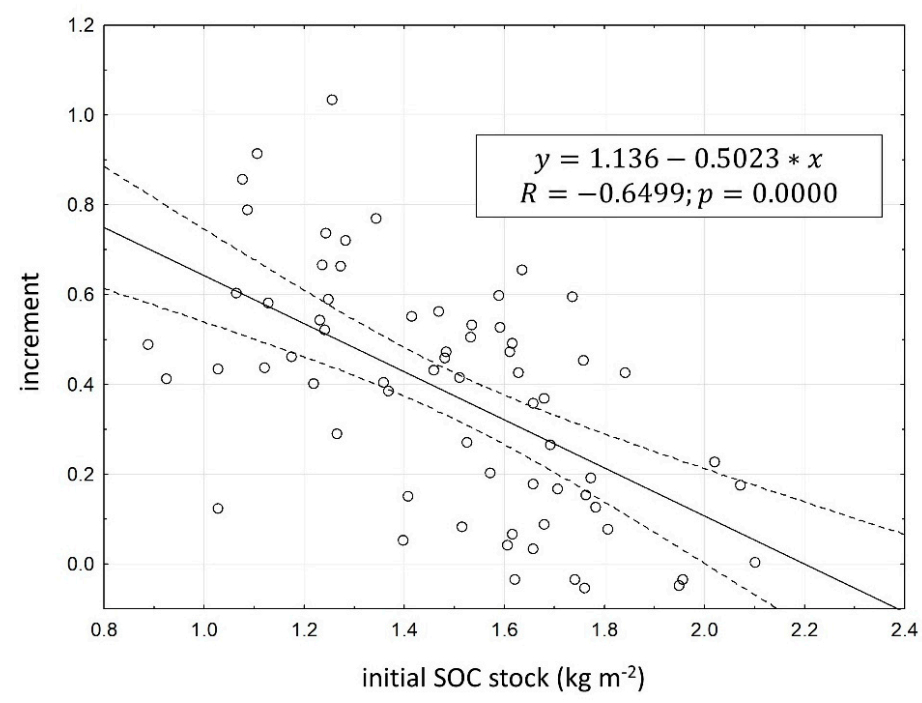

Figure 2. Relationship between increment (difference between the SOC stock measured after 6 years of SRC and that at the starting point at the same locations) and initial SOC stock (H-SRC and VH-SRC considered together) and its $95 \%$ confidence interval. 
By applying the appropriate model to each SRC type, we obtained for H-SRC an average 6-years SOC increment of $0.46 \mathrm{~kg} \mathrm{~m}^{-2}$, resulting in an average SOC stock of $1.91 \mathrm{~kg} \mathrm{~m}^{-2}$ while at VH-SRC the increment was lower $\left(0.22 \mathrm{~kg} \mathrm{~m}^{-2}\right)$, resulting in an average SOC stock of $1.79 \mathrm{~kg} \mathrm{~m}^{-2}$ (Figure 3).

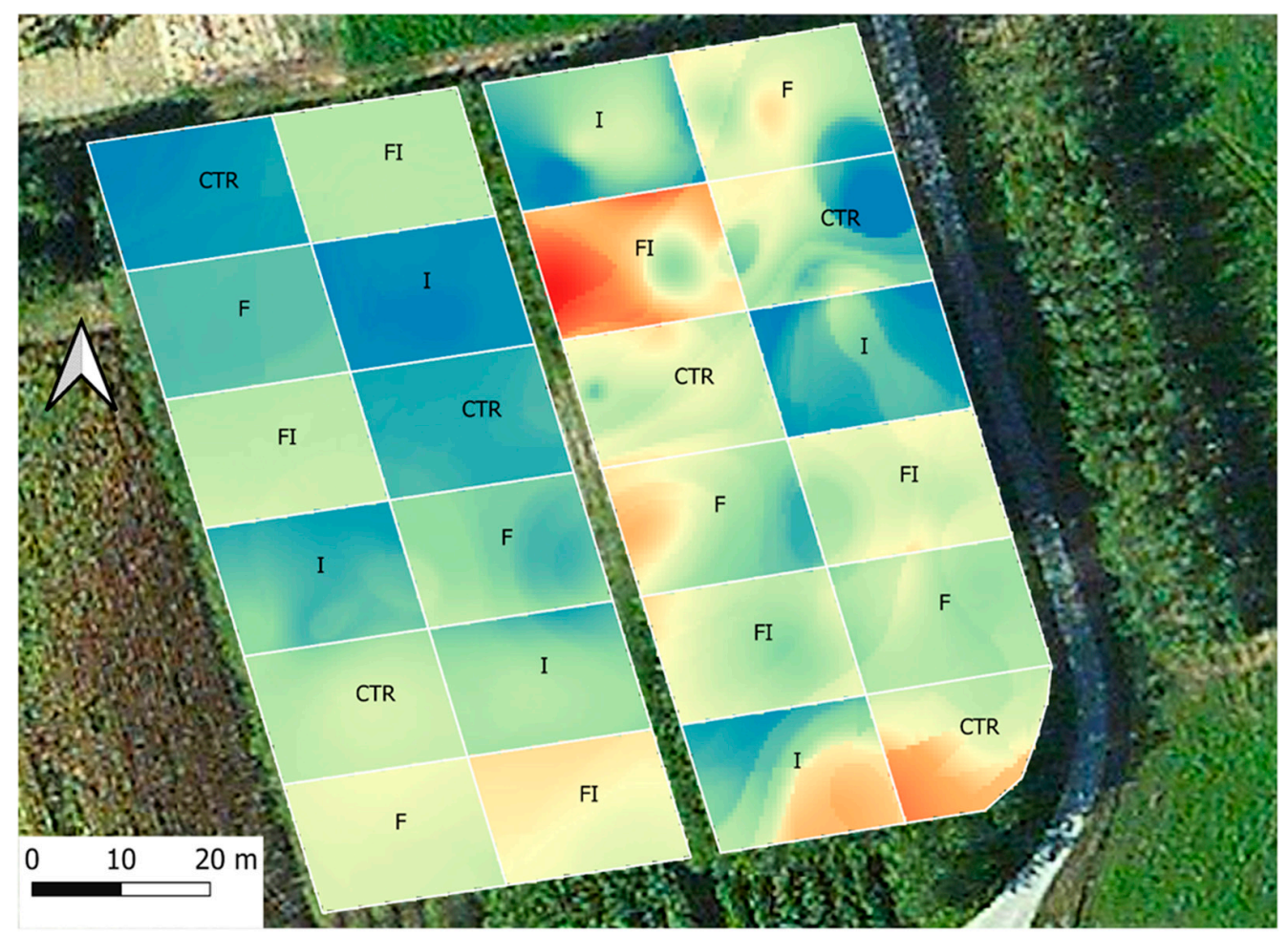

Figure 3. Map of 6-year increments of SOC stock $\left(\mathrm{kg} \mathrm{m}^{-2}\right)$ distinguishing treatments in H-SRC (on the right) and VH-SRC (on the left). The overlapping white grid represents the agronomic treatment model. FI: fertilization and irrigation; I: irrigation; F: fertilization; CTR: control.

With regard to the changes in SOC stock by type of treatment, in H-SRC an increase of $0.48 \pm 0.21 \mathrm{~kg} \mathrm{~m}^{-2}, 0.45 \pm 0.04 \mathrm{~kg} \mathrm{~m}^{-2}, 0.62 \pm 0.22 \mathrm{~kg} \mathrm{~m}^{-2}$, and $0.29 \pm 0.16 \mathrm{~kg} \mathrm{~m}^{-2}$ was observed for CTR, F, FI, and I, respectively, while in VH-SRC the SOC stock increased by $0.15 \pm 0.17 \mathrm{~kg} \mathrm{~m}^{-2}, 0.25 \pm 0.14 \mathrm{~kg} \mathrm{~m}^{-2}, 0.38 \pm 0.10 \mathrm{~kg} \mathrm{~m}^{-2}$, and $0.12 \pm 0.13 \mathrm{~kg} \mathrm{~m}^{-2}$ for CTR, F, FI, and I, respectively.

\section{Discussion}

After 6 years of SRC, the SOC stock increased by about $30 \%\left(0.076 \mathrm{~kg} \mathrm{~m}^{-2} \mathrm{year}^{-1}\right)$ and $14 \%\left(0.037 \mathrm{~kg} \mathrm{~m}^{-2}\right.$ year $\left.^{-1}\right)$ in the $0-15 \mathrm{~cm}$ layer of H-SRC and VH-SRC, respectively, confirming the potential of poplar energy crops to sequester carbon in soil if established on former cropland, as found in the review of Don et al. (2012) [12] that reported an average SOC accumulation of $0.044 \mathrm{~kg} \mathrm{~m}^{-2}$ year $^{-1}$; however, the accumulation rates strongly differ between studies (e.g., $0.03 \mathrm{~kg} \mathrm{C} \mathrm{ha}^{-1}$ year $^{-1}$, [15]; $0.16 \mathrm{~kg} \mathrm{C} \mathrm{ha}^{-1}$ year $^{-1}$, [25]). The differences found in the literature may be due not only to differences in the cultivated species or in the SRC management, but also to the soil characteristics and SOC stock before conversion $[3,20,37]$. We clearly observed the influence of the initial SOC on its accumulation during SRC system: soils with lower initial SOC showed higher accumulation.

Several factors may have played a role in the observed SOC accumulation as a consequence of conversion from cropland to SRC, among which the fact that plantations generally result in increased litter and root inputs compared to annually harvested crops [19].

In addition, the soil disturbance is strongly limited: deep ploughing is done only before establishing the plantation, and not annually as for most of the crops, decreasing $\mathrm{SOC}$ heterotrophic oxidation due to lower soil $\mathrm{O}_{2}$ input [38]. In our study, the weed control 
by harrowing was the only tillage operation in addition to pre-planting ploughing; soil was harrowed more frequently in the first 2 years of plantation causing SOC loss through mineralization, but at the same time allowing incorporation of weed organic matter into the first soil layer. A non-involvement of the deeper layers as a consequence of SRC was found, as also shown in other studies $[3,16,19,39,40]$.

The SOC storage may also be related to a decrease in soil surface temperature due to the poplar canopy cover, which may have caused a decrease in organic matter mineralization. The effect of temperature on soil respiration was observed since the first year of the plant in VH-SRC [18] although the canopy extensions of the young standwere still limited.

Our study evaluated the SOC changes after 6 years of SRC, starting from 2010, the second year of planting; assuming a starting SOC stock equal to that of the second layer investigated in the first sampling, representing the SOC stock after pre-planting ploughing at $35 \mathrm{~cm}$, the average $\mathrm{SOC}$ stock increase would be higher than that previously estimated: $0.080 \mathrm{~kg} \mathrm{~m}^{-2}$ year $^{-1}$ and $0.053 \mathrm{~kg} \mathrm{~m}^{-2}$ year $^{-1}$ for H-SRC and VH-SRC, respectively. The higher accumulation rate in the first year of SRC, as above indicated, may be the consequence of a higher incorporation of weeds into the soil through harrowing [41], compared to the following years characterized by lower weed production due to the higher tree density and canopy cover.

By SRCs comparison, H-SRC resulted to accumulate more SOC stock than VH-SRC. Concerning this, Bergante et al. (2015) [42] found that H-model was the most productive; the total epigeal biomass production averaged to $11.78 \mathrm{t} \mathrm{ha}^{-1}$ at the end of 5 th year compared to $7.98 \mathrm{t} \mathrm{ha}^{-1}$ of the $\mathrm{VH}$-model, but no differences in leaf biomass (average value of $3.5 \pm 0.19 \mathrm{t} \mathrm{ha}^{-1}$ in 5 years) were found between the two SRC models. Since poplar hypogeal biomass is usually positively correlated with epigeal biomass [43], the contribution of SOM from roots helps to explain the higher storage of SOM at H-SRC compared to VH-SRC.

SOC stock differences between the two SRC types could also be related to differences in organic matter mineralization rates due to different soil temperatures or water content. As previously reported, a lower soil temperature, and thus soil respiration, was observed in the first-planting-year in VH-SRC compared to H-SRC; this temperature difference was likely canceled during the next 4 years as a result of tree growth in H-SRC in the absence of cutting. The higher RF content of H-SRC than that of VH-SRC may also have limited water availability by decreasing microbial activity and organic matter mineralization. Evaluating treatment effects on SOC accumulation, we found a positive influence of irrigation associated with fertilization, with an average increment in 6 years of SRC of $0.62 \mathrm{~kg} \mathrm{~m}^{-2}$ and $0.38 \mathrm{~kg} \mathrm{~m}^{-2}$ for H-SRC and VH-SRC, respectively. The water availability is considered a key factor for a high plantation productivity [28], particularly in soils with loose texture and deep water table, such as those studied. Concerning fertilization, conflicting results are reported: Scholz et al. (2010) [15] observed an increase in SOC stock of fertilized compared with non-fertilized SRC plots, while Ventura et al. (2019) [13] reported that neither $\mathrm{N}$ nor ash application affects SOC variation; at the moment, the correlation between fertilization and SOC accumulation is still poorly investigated and unclear and needs further studies.

The spatial survey adopted in our study let us identify a relevant spatial variability of SOC, texture, and RF contents and consequently of the distribution of SOC stock at the starting-point.

Despite the non-homogeneous distribution of RF within the study area, the agronomic treatments were quite balanced. In H-SRC, where RF extended over more than half the field, only one CTR replication was not representative of the block to which it belonged, probably leading to an average value of SOC accumulation in CTR comparable to that of $\mathrm{F}$ and higher than that of I.

The identification of the model, which includes the influence of the initial SOC and the agronomic treatments on SOC storage, combined with the spatial approach, provided a more accurate SOC accumulation value, in particular for H-SRC module for which a lower 
SOC stock increase ( $27 \%$ instead of $30 \%$ ) would have been estimated considering the points only (albeit in large numbers).

\section{Conclusions}

We investigated the medium-term impact of land use conversion from cropland to poplar SRC on SOC stock, comparing high-density and very-high-density models and evaluating the agronomic treatment effects on SOC accumulation.

The study showed evidence that: (i) poplar SRCs contribute to SOC storage confirming their role in producing bio-energy while also providing a potential mitigation effect on climate change; (ii) during 6 years of planting, H-SRC accumulated more SOC than VHSRC, mainly related to its higher biomass productivity; (iii) irrigation associated with fertilization significantly increased SOC accumulation rate; similar relevance had the SOC content before conversion; (iv) spatial variability survey represented a valid approach to obtain an accurate SOC stock evaluation, especially in areas with a strong spatial variability of soil properties.

Author Contributions: Formal analysis, C.F., G.M. and R.C.; Investigation, C.F. and R.C.; Methodology, C.F. and R.C.; Writing-original draft, C.F., G.M. and R.C.; Writing-review \& editing, C.F., G.M. and R.C. All authors have read and agreed to the published version of the manuscript.

Funding: This research was funded by the Italian Ministry of Agricultural, Food and Forestry Policies.

Institutional Review Board Statement: "Not applicable" for studies not involving humans or animals.

Informed Consent Statement: Informed consent was obtained from all subjects involved in the study.

Data Availability Statement: The data presented in this study are available on request from the corresponding author.

Acknowledgments: This work was supported by the SUSCACE project. Special thanks to L. Ballabio and M.S. Fusco for their field support and to G. Facciotto and S. Bergante of CREA-PLF (Casale Monferrato, Italy) for site management information.

Conflicts of Interest: The authors declare no conflict of interest. The funders had no role in the design of the study; in the collection, analyses, or interpretation of data; in the writing of the manuscript, or in the decision to publish the results.

\section{References}

1. Sartori, F.; Lal, R.; Ebinger, M.H.; Parrish, D.J. Potential soil carbon sequestration and $\mathrm{CO}_{2}$ offset by dedicated energy crops in the USA. Crit. Rev. Plant Sci. 2006, 25, 441-472. [CrossRef]

2. Guo, M.; Li, C.; Facciotto, G.; Bergante, S.; Bhatia, R.; Comolli, R.; Ferré, C.; Murphy, R. Bioethanol from poplar clone Imola: An environmentally viable alternative to fossil fuel? Biotechnol. Biofuels 2015, 8, 1-21. [CrossRef] [PubMed]

3. Georgiadis, P.; Vesterdal, L.; Stupak, I.; Raulund-Rasmussen, K. Accumulation of soil organic carbon after cropland conversion to short-rotation willow and poplar. GCB Bioenergy 2017, 9, 1390-1401. [CrossRef]

4. Oliveira, N.; Rodríguez-Soalleiro, R.; Pérez-Cruzado, C.; Cañellas, I.; Sixto, H.; Ceulemans, R. Above-and below-ground carbon accumulation and biomass allocation in poplar short rotation plantations under Mediterranean conditions. For. Ecol. Manag. 2018, 428, 57-65. [CrossRef]

5. Berhongaray, G.; Verlinden, M.S.; Broeckx, L.S.; Janssens, I.A.; Ceulemans, R. Soil carbon and belowground carbon balance of a short-rotation coppice: Assessments from three different approaches. GCB Bioenergy 2017, 9, 299-313. [CrossRef]

6. Aylott, M.J.; Casella, E.; Tubby, I.; Street, N.R.; Smith, P.; Taylor, G. Yield and spatial supply of bioenergy poplar and willow short-rotation coppice in the UK. New Phytol. 2008, 178, 358-370. [CrossRef] [PubMed]

7. Dimitriou, I.; Busch, G.; Jacobs, S.; Schmidt-Walter, P.; Lamersdorf, N. A review on the impact of Short Rotation Coppice cultivation on water issues. Agric. For. Res. 2009, 59, 197-206.

8. Kahle, P.; Janssen, M. Impact of short-rotation coppice with poplar and willow on soil physical properties. J. Plant Nutr. Soil Sci. 2020, 183, 119-128. [CrossRef]

9. Kuzovkina, Y.A.; Volk, T.A. The characterization of willow (Salix L.) varieties for use in ecological engineering applications: Co-ordination of structure, function and autecology. Ecol. Eng. 2009, 35, 1178-1189. [CrossRef]

10. Lasch, P.; Kollas, C.; Rock, J.; Suckow, F. Potentials and impacts of short-rotation coppice plantation with aspen in Eastern Germany under conditions of climate change. Reg. Environ. Chang. 2010, 10, 83-94. [CrossRef] 
11. Agostini, F.; Gregory, A.S.; Richter, G.M. Carbon sequestration by perennial energy crops: Is the jury still out? Bioenerg. Res. 2015, 8, 1057-1080. [CrossRef] [PubMed]

12. Don, A.; Osborne, B.; Hastings, A.; Skiba, U.; Carter, M.S.; Drewer, J.; Flessa, H.; Freibauer, A.; Nen, N.H.; Jones, M.B.; et al. Land-use change to bioenergy production in E urope: Implications for the greenhouse gas balance and soil carbon. GCB Bioenergy 2012, 4, 372-391. [CrossRef]

13. Ventura, M.; Panzacchi, P.; Muzzi, E.; Magnani, F.; Tonon, G. Carbon balance and soil carbon input in a poplar short rotation coppice plantation as affected by nitrogen and wood ash application. New For. 2019, 50, 969-990. [CrossRef]

14. Bergante, S.; Facciotto, G.; Minotta, G. Identification of the main site factors and management intensity affecting the establishment of Short-Rotation-Coppices (SRC) in Northern Italy through stepwise regression analysis. Open Life Sci. 2010, 5, 522-530. [CrossRef]

15. Hellebrand, H.J.; Strähle, M.; Scholz, V.; Kern, J. Soil carbon, soil nitrate, and soil emissions of nitrous oxide during cultivation of energy crops. Nutr. Cycl. Agroecosys. 2010, 87, 175-186. [CrossRef]

16. Ceotto, E.; Di Candilo, M. Medium-term effect of perennial energy crops on soil organic carbon storage. Ital. J. Agron. 2011, 6, e33. [CrossRef]

17. Verlinden, M.S.; Broeckx, L.S.; Wei, H.; Ceulemans, R. Soil $\mathrm{CO}_{2}$ efflux in a bioenergy plantation with fast-growing Populus trees-influence of former land use, inter-row spacing and genotype. Plant Soil 2013, 369, 631-644. [CrossRef]

18. Ferre, C.; Comolli, R. Comparison of soil $\mathrm{CO}_{2}$ emissions between short-rotation coppice poplar stands and arable lands. iForest 2018, 11, 199. [CrossRef]

19. Ferchaud, F.; Vitte, G.; Mary, B. Changes in soil carbon stocks under perennial and annual bioenergy crops. GCB Bioenergy 2016, 8 , 290-306. [CrossRef]

20. Rowe, R.L.; Keith, A.M.; Elias, D.; Dondini, M.; Smith, P.; Oxley, J.; McNamara, N.P. Initial soil C and land-use history determine soil C sequestration under perennial bioenergy crops. GCB Bioenergy 2016, 8, 1046-1060. [CrossRef]

21. Harris, Z.M.; Spake, R.; Taylor, G. Land use change to bioenergy: A meta-analysis of soil carbon and GHG emissions. Biomass Bioenerg. 2015, 82, 27-39. [CrossRef]

22. Morrison, R.; Rowe, R.L.; Cooper, H.M.; McNamara, N.P. Multi-year carbon budget of a mature commercial short rotation coppice willow plantation. GCB Bioenergy 2019, 11, 895-909. [CrossRef]

23. Hoosbeek, M.R.; Lukac, M.; van Dam, D.; Godbold, D.L.; Velthorst, E.J.; Biondi, F.A.; Peressotti, A.; Cotrufo, M.F.; de Angelis, P.; Scarascia-Mugnozza, G. More new carbon in the mineral soil of a poplar plantation under Free Air Carbon Enrichment (POPFACE): Cause of increased priming effect? Glob. Biogeochem. Cycles 2004, 18, 1-7. [CrossRef]

24. Sierra, M.; Martínez, F.J.; Verde, R.; Martín, F.J.; Macías, F. Soil-carbon sequestration and soil-carbon fractions, comparison between poplar plantations and corn crops in south-eastern Spain. Soil Tillage Res. 2013, 130, 1-6. [CrossRef]

25. Arevalo, C.B.; Bhatti, J.S.; Chang, S.X.; Sidders, D. Land use change effects on ecosystem carbon balance: From agricultural to hybrid poplar plantation. Agric. Ecosyst. Environ. 2011, 141, 342-349. [CrossRef]

26. Verlinden, M.S.; Broeckx, L.S.; Zona, D.; Berhongaray, G.; De Groote, T.; Serrano, M.C.; Janssens, I.A.; Ceulemans, R. Net ecosystem production and carbon balance of an SRC poplar plantation during its first rotation. Biomass Bioenerg. 2013, 56, 412-422. [CrossRef]

27. IUSS Working Group. World Reference Base for Soil Resources 2014, Update 2015; World Soil Resources Reports; FAO: Rome, Italy, 2015; Volume 103, p. 192.

28. Bergante, S.; Facciotto, G.; Marchi, M. Growth dynamics of 'Imola' poplar clone (Populus $\times$ canadensis Mönch) under different cultivation inputs. Ann. Silvic. Res. 2020, 44, 71-79.

29. Harris, D.; Horwath, W.R.; Van Kess, E.C. Acid fumigation of soils to remove carbonates prior to total organic carbon or carbon-13 isotopic analysis. Soil Sci. Soc. Am. J. 2001, 65, 1853-1856. [CrossRef]

30. Burt, R. Soil survey laboratory methods manual. In Soil Survey Investigations 2004, Report 42, Version 4.0; United States Department of Agriculture: Washington, DC, USA, 2004.

31. Matheron, G. Pour une Analyse Krigeante des Donnees Regionalisees; Technical Report No. 732; Centre de Geostatistique: Fontainebleau, France, 1982.

32. Chilès, J.P.; Delfiner, P. Discrete exact simulation by the Fourier method. In Geostatistics Wallagong '96; Baafi, E.Y., Schofield, N.A., Eds.; Kluwer Academic Publishers: Cham, The Netherlands, 1997; Volume I, pp. 258-269.

33. Wackernagel, H. Multivariate Geostatistics: An Introduction with Applications, 3rd ed.; Springer Science \& Business Media: Berlin, Germany, 2013.

34. Geovariances. Isatis Technical Ref., Ver. 2013.1; Geovariances \& Ecole Des Mines De Paris: Paris, France, 2020.

35. Searle, S.R.; Casella, G.; McCulloch, C.E. Variance Components; John Wiley \& Sons: Hoboken, NJ, USA, 2009.

36. Littell, R.C.; Milliken, G.A.; Stroup, W.W.; Wolfinger, R.D.; Schabenberger, O. SAS for Mixed Models; SAS Institute: Cary, NC, USA, 2006.

37. Tolbert, V.R.; Todd, D.E., Jr.; Mann, L.K.; Jawdy, C.M.; Mays, D.A.; Malik, R.; Bandaranayake, W.; Houston, A.; Tyler, D.; Pettry, D.E. Changes in soil quality and below-ground carbon storage with conversion of traditional agricultural crop lands to bioenergy crop production. Environ. Pollut. 2002, 116, S97-S106. [CrossRef]

38. Haddaway, N.; Hedlund, K.; Jackson, L.; Kätterer, T.; Lugato, E.; Thomsen, I.; Bracht Jørgensen, H.; Isberg, P. How does tillage intensity affect soil organic carbon A systematic review. Environ. Evid. 2017, 6, 30. [CrossRef] 
39. Walter, K.; Don, A.; Flessa, H. No general soil carbon sequestration under Central European short rotation coppices. GCB Bioenergy 2015, 7, 727-740. [CrossRef]

40. Lockwell, J.; Guidi, W.; Labrecque, M. Soil carbon sequestration potential of willows in short-rotation coppice established on abandoned farm lands. Plant Soil 2012, 360, 299-318. [CrossRef]

41. Huang, M.; Chen, G.; Cao, F.; Chen, J. Estimating Carbon Fixation Potential of Fallow Weeds in Rice Cropping Systems. Res. Sq. 2020. [CrossRef]

42. Bergante, S.; Facciotto, G. Yields of poplar SRC and VSRC grown with different fertilization and irrigation management. In Proceedings of the 23th European Biomass Conference and Exhibition, Vienna, Austria, 1-4 June 2015; pp. 1-4.

43. Phillips, C.J.; Marden, M.; Suzanne, L.M. Observations of root growth of young poplar and willow planting types. N. Z. J. For. Sci. 2014, 44, 1-12. [CrossRef] 